\title{
Evolution of Materials Engineering Education at Memorial University
}

\author{
John Shirokoff, Ph.D., P.Eng. \\ Associate Professor, Faculty of Engineering \& Applied Science \\ Memorial University of Newfoundland \\ shirokof@mun.ca
}

\begin{abstract}
The development and evolution of materials engineering education at Memorial University of Newfoundland has been reviewed. The faculty of engineering discipline structure has played a role in the way undergraduate materials engineering courses are offered to students. Materials research has increased the number of undergraduate and graduate courses that are offered over time owing to materials research funding, publications, research institutions and centres activities improve materials education at the undergraduate and graduate level and these topics are discussed.
\end{abstract}

\section{Introduction}

The history of materials engineering (formerly metallurgy) from an industrial point of view can be found in part in several publications and websites [12]. These items often deal with non-fiction selected aspects of the history of metallurgy from the early refining of metals and alloys followed by the technological evolution and development of methods to further refine and process products. Simultaneously, the history of materials education has evolved, often within the context of engineering, science, technology and innovation at colleges and universities. Since materials education has mostly evolved under the auspices of institutions of higher learning this evolution is usually embedded in education programs (i.e. engineering schools, departments, curriculum etc.) that are created and then updated over time [3-5]. Efforts are underway to compile a brief history of materials education and research from various engineering schools across Canada [6]. It is therefore the purpose of this paper to report on some aspects of the evolution of materials education at Memorial University in terms of history, disciplines, undergraduate and graduate courses, materials research, and other activities.

\section{History}

The history of materials education at Memorial University dates back to 1925 when Memorial College was founded. At that time the college offered first and second year courses leading to degree programs (i.e. arts, science, engineering etc.) at various universities in eastern and central Canada (i.e. Dalhousie University, Nova Scotia Technical College, McGill University etc.). Newfoundland became a Canadian province in 1949, and this led to the creation of Memorial University of Newfoundland (MUN) by provincial statute.

Engineering was started as a diploma program in the 1930s with basic training in chemistry, mathematics and physics, followed by the addition of mechanics and materials in the 1940s [6].

In 1969-1970, Memorial added a co-op engineering program composed of three engineering disciplines in civil, electrical and mechanical engineering. Essentially four core courses included two in chemistry and two engineering materials courses were studied. A materials engineering option for the senior three semesters included more materials courses of which physical metallurgy and production technology (manufacturing) sustained. In the 1980s the engineering accreditation process defined the shipbuilding engineering component as ocean and naval architectural engineering. Engineering remained un-departmentalized and structured with four disciplines (civil, electrical, mechanical, and naval architectural). Computer engineering was incorporated into the electrical engineering discipline in the 1990s and a fifth discipline called process engineering was created in 2009 which will be reviewed by the next Canadian engineering accreditation board (CEAB) process in 2014.

\section{Disciplines}

There are five disciplines (electrical-computer, civil, process, mechanical, naval-architecture) in the 
faculty of engineering at Memorial University. With this type of faculty structure course offerings by any discipline can be combined to create efficiency in teaching lectures, laboratories and tutorials. By design it creates more courses as options at the senior undergraduate and graduate student level. This design benefits senior undergraduate and graduate student teaching with smaller class sizes (i.e. 5-50 students). One can also argued that it disadvantages junior level undergraduate classes burdened with larger class size (i.e. 100 to 200 students).

The faculty of engineering in the past has been viewed as a unit similar to a department. Since several disciplines are small (civil, process, navalarchitecture) they are more efficiently administered by one general office. The larger disciplines (electricalcomputer, mechanical) gain less in efficiency by collaboration and could easily be departmentalized individually or departmentalized in combination with a smaller discipline. Why is this important? All things considered (i.e. teaching quality, class size, course overlap, office-class-laboratory space, staff, faculty, retention and turnover of personnel, administrators, budgets, coop placement, university policies, union agreements etc.) the critical mass, growth, and size of a unit affects performance in ways that are seldom measured. In this context, materials courses continue to be offered in the disciplines of engineering based on several criteria such as, CEAB accreditation, student interest, faculty and technical staff to teach the course components (lectures, tutorials, and laboratories).

\section{Undergraduate Materials Courses}

Historically several materials courses were part of the core undergraduate engineering program while several materials courses were available as optional courses for senior semester undergraduate engineering students. Table 1 defines undergraduate materials engineering education courses at Memorial University over the period of 1925 to 2011.

From the 1970s to the period 1990-2011 the CEAB process has required the faculty of engineering at Memorial University to rename materials I and II to properly reflect the content of these courses (i.e. physics and chemistry of engineering materials I and II). Mechanical engineering students are required to take the first three materials courses (physics and chemistry of engineering materials I and II, and production technology) while the next three materials courses (industrial materials, corrosion and corrosion control, fatigue and fracture mechanics) are optional electives. The civil engineering students are required to take materials of construction, mechanics of solids I and II, and optional elective advanced mechanics of deformable solids. Students in ocean-architectural engineering and process engineering are required to take physics and chemistry of engineering materials I. An optional elective course on mining and metallurgical process engineering is proposed for process engineering students in 2011-2012. The electrical and computer engineering students are no longer required to take any materials courses and their program has introduced an alternate course from the physics department at Memorial called physics of device materials.

Table 1. Undergraduate materials courses 1925 to 2011

\begin{tabular}{|c|c|}
\hline $\begin{array}{l}\text { MUN Program } \\
\text { Year }\end{array}$ & $\begin{array}{ll}\text { Undergraduate } & \text { Materials } \\
\text { Courses } & \end{array}$ \\
\hline 1925 & $\begin{array}{l}\text { Chemistry I } \\
\text { Chemistry II }\end{array}$ \\
\hline 1940 & $\begin{array}{l}\text { Chemistry I } \\
\text { Chemistry II } \\
\text { Mechanics }\end{array}$ \\
\hline 1970 & $\begin{array}{l}\text { Chemistry I } \\
\text { Chemistry II } \\
\text { Materials I } \\
\text { Materials II } \\
\end{array}$ \\
\hline $1990-2011$ & $\begin{array}{l}\text { Physics and Chemistry of } \\
\text { Engineering Materials I } \\
\text { Physics and Chemistry of } \\
\text { Engineering Materials II } \\
\text { Production Technology } \\
\text { Industrial Materials } \\
\text { Corrosion and Corrosion Control } \\
\text { Fatigue and Fracture Mechanics } \\
\text { Materials of Construction } \\
\text { Mechanics of Solids I } \\
\text { Mechanics of Solids II } \\
\text { Advanced Mechanics of } \\
\text { Deformable Solids } \\
\text { Mining and Metallurgical Process } \\
\text { Engineering }\end{array}$ \\
\hline
\end{tabular}

\section{Graduate Materials Courses}

Graduate courses have been offered to graduate students both continuously and intermittently in order to suite the growing demand for students performing research based thesis towards Masters and $\mathrm{PhD}$ degrees from about 1970 to 2011. Some of these graduate courses are listed in table 2. 
Table 2. Typical graduate materials courses 1970 to 2011

\begin{tabular}{|l|l|}
\hline $\begin{array}{l}\text { MUN Program } \\
\text { Year }\end{array}$ & Graduate Materials Courses \\
\hline $1970-2011$ & Solid and Structural Mechanics \\
& Advanced Fatigue and Fracture \\
& Mechanics \\
& Advanced Corrosion \\
& Materials Characterization \\
& Biomedical Engineering \\
\hline
\end{tabular}

The author apologizes if some graduate courses have not been included since when faculty members retire often the individuals course information on their websites can go offline and become difficult to retrieve.

\section{Materials Research}

Materials research and research in many engineering areas increased around the time period of 1975-1976 when the faculty of engineering was relocated into a new building (S.J. Carew building) equipped with many new laboratories and facilities (e.g. metallurgy laboratory, structures laboratory, cement and concrete laboratory, ocean and naval architecture laboratory, fluids laboratory etc.). In addition, C-CORE in 1975 and the National Research Council of Canada (NRC)-Institute of Ocean Technology (IOT) in 1985 were established at Memorial in buildings on either side of the faculty of engineering premises. The former (C-CORE) is a research and development corporation of Memorial University that provides innovative engineering solutions to clients in the natural resource sectors and government. They study many topics including offshore oil and gas, gas transmission, mining, hydro, and ice research, for example. NRC-IOT conducts a wide range of research related to ocean, naval, ice, offshore and arctic issues, for example. Subsequent to this period in engineering research Memorial University created an Inco Innovation Centre in 2003 in order to expand geophysics, geology, geochemistry, and process engineering (i.e. chemical, corrosion, process control, risk and safety etc.) activities.

Table 3 lists several materials research topics studied at Memorial University. This table of materials research topics periodically expands and contracts based on the faculty of engineering and applied science turnover, research interests, research funding and collaborative research projects at Memorial University and in the general research community.
It is well known that the amount of research has increased over time at Memorial University. Research funding is often a requirement to grow and sustain research programs. These sources have come from federal grant sources (i.e. Atlantic Canada Opportunities Agency (ACOA), Canadian Foundation for Innovation (CFI), Natural Sciences and Engineering Research Council of Canada (NSERC), etc.), provincial (Research and Development Corporation-Newfoundland and Labrador (RDC-NL)), University (Leslie Harris Centre of Regional Policy and Development, Memorial University). Research publication such as journal papers, conference papers, and books have also grown over this period, and evidence of publication can be found through links to publication on the faculty website [7].

Table 3. Example materials research topics at Memorial University of Newfoundland (MUN) 1970 to 2011

\begin{tabular}{|c|c|}
\hline $\begin{array}{l}\text { MUN } \\
\text { Program } \\
\text { Year }\end{array}$ & $\begin{array}{l}\text { Examples of Materials Research } \\
\text { Topics }\end{array}$ \\
\hline $1970-2011$ & $\begin{array}{l}\text { Asphalt and Asphalt Binders } \\
\text { Biomaterials } \\
\text { Biomedical Materials } \\
\text { Cement and Concrete } \\
\text { Corrosion \& Protection Materials (in } \\
\text { i.e. Seawater, Hydrometallurgy etc.) } \\
\text { Fatigue and Fracture Mechanics } \\
\text { Fibreglass Reinforced Polymers } \\
\text { Hydrometallurgy } \\
\text { Ice Mechanics } \\
\text { Metal and Alloys } \\
\text { Nanomaterials } \\
\text { Opto-electronic Materials } \\
\text { Polymers } \\
\text { Semiconductors } \\
\text { Solid State Sensors } \\
\text { Solid and Structural Mechanics } \\
\text { Thin Films and Multilayers } \\
\text { Tribology } \\
\text { Wear }\end{array}$ \\
\hline
\end{tabular}

\section{Other Activities}

In general, the faculty of engineering and Memorial University has been active in various programs over the years such as industrial outreach (i.e. service contracts to industrial clients, consulting etc.), creating technology and development centres (manufacturing, oceans, arctic, regional policy and 
development etc.). These activities indirectly contribute to various aspects of materials education [8].

\section{Conclusions}

A review of materials education at Memorial University has indicated that the number of undergraduate and graduate courses offered has increased over time. The way in which materials courses are offered to students involves engineering faculty disciplines, accreditation, and student interest. The growth in materials education has benefitted from research funding, publication, and additional factors such as research institutions and centres.

\section{Acknowledgements}

The author would like to acknowledge Memorial University of Newfoundland for supporting this conference and publication.

\section{References}

[1] M.L Wayman, ed., All that Glitters: Readings in Historical Metallurgy, The Metallurgical Society of the Canadian Institute of Mining and Metallurgy, Montreal, 1989, pp. 1-197.

[2] Historical Metallurgical Committee, The Metallurgical Society of the Canadian Institute of Mining and Metallurgy, www.metsoc.org/; April, 2011.

[3] University of British Columbia (UBC) Materials Engineering - History of Materials Engineering, www.mmat.ubc.ca/about/history/index.php; April, 2011.
[4] The History of Materials at Georgia Tech, www.mse.gatech.edu/about-the-school-/history; April, 2011.

[5] University of Wollongong - Materials Engineering - Homepage and History, www.uow.edu.au/eng/mmm/mat/history/index; April, 2011.

[6] J. Molgaard, J. Shirokoff, Materials Education and Research at Memorial University, in M.L. Wayman (ed.), History of Metallurgy in Canada, The Metallurgical Society of the Canadian Institute of Mining and Metallurgy, Montreal, 2011, pp. 1-5 (in press).

[7] Memorial University, Faculty of Engineering and Applied Science, http://www.engr.mun.ca/people/ alam/; bachmayer/; sbruneau/; colbourne.php; ccoles; cdaley/; mhaddara/; hassan.php; amyhsiao/; jordaan/; kenny/; llye/; vmasek; molgaard/; peng.php; qiuw; rahman, shirokof/; swamidas/; jyang/; zhang.php; lihong/; corresponding to links to additional information on materials related publications on the webpages of Drs Alam, Bachmayer, Bruneau, Colbourne, Coles, Daley, Haddara, Hassan, Hsiao, Jordaan, Kenny, Lye, Masek, Molgaard, Peng, Qiu, Rahman, Shirokoff, Yang, B. Zhang, L. Zhang, and others, April, 2011.

[8] A. Hsiao, Nanomaterials in Newfoundland: Designing a Lab Kit for Grades 9-12 to Bridge the Gap Between Science and Engineering, Proceedings of The Canadian Engineering Education Association (CEEA) -First Annual Conference, 2010, pp. 1-6. 